\title{
SIMULATIONS AS MENTAL TOOLS FOR NETWORK-BASED GROUP LEARNING
}

\author{
Miika Lehtonen \\ University of Lapland
}

\begin{abstract}
The article presents pedagogical and technological applications developed and studied as part of the research project 'Web-supported Mental Tools in Technology Education' at the University of Lapland. The applications allow simulation tools, modern network-based solutions that support learning, and other mental tools, as well as traditional and modern digital learning materials, to be smoothly integrated into normal teaching-studying-learning activity. For example, efforts have been made make use of edutainment as part of the nature of tools and materials and game-like interactivity to enhance the learning process. The broader framework for the model of learning activity that is being developed and studied in the project centers on the question how and through which learning activity (learning process) study and learning in the field of electric technology and electronics (technical work and technology education) can be organized to take into account the challenges posed by the post-industrial information society.
\end{abstract}

Key words: Distance Learning, Games, Learning Models, Research, Simulation

\section{INTRODUCTION}

In a somewhat light-hearted vein, one could say that high-level work on the part of a teacher - teaching, and the work of a magician - the creation of an illusion, are closely related. The magician's task is to create an emotionally engaging situation and atmosphere and guide the viewer to focus on the inessential; the aim of a teacher - or the computer or network teaching application in this project — is to guide a student or group of students to see, do and discover what is essential in the focal content and to create an emotionally appropriate context for that learning. We might say that both the teacher and magician try to guide observations and emotions 
and use different tools to that end. Adapting Galperin's terminology, we can refer to this guiding of observations in appropriate or inappropriate directions as orientation (e.g., Galperin 1979; Podolskij 1997).

In using various computer and network-based learning tools, such as the simulations in electronic technology and electronics used in the present project (e.g., Lehtonen 2002a,b,c), the observations presented above on steering the student or group of students are at least as salient as they are in conventional teaching. The activity which students are guided to engage in through teaching - study (Uljens 1997) will frequently not take place in an optimal fashion solely by using the most modern tools; we must at the same time guide or orient the student to use those tools in a manner appropriate for studying. Indeed, although the terms used in teaching have changed in many particulars to the more modern-sounding "learning", the problem of teaching and guiding is still very much with us. Although we speak of constructive learning, for example, teaching itself, guiding and focusing students' studying, i.e., orienting them towards what is essential has by no means disappeared. The following sections provide an exploration of the theoretical key ideas and their implications for guiding students on network-based group learning situations with simulations.

\section{SIMULATIONS AND MODERN AND TRADITIONAL MEDIA AS A NATURAL PART OF THE STUDYING PROCESS}

The aim of this article is to present the underpinnings of the learning activity that is being elaborated in the action research project "Websupported Mental Tools in Technology Education" ( $N=9$, third- and fourthyear preservice teachers on a technology education course). Theses principles allow simulation tools, modern network-based solutions that support learning, and other mental tools (e.g., Jonassen 2000), as well as traditional and modern digital learning materials, to be smoothly integrated into normal teaching-studying-learning activity in typical university-level study. The project has undertaken to analyze the advantages and disadvantages of different tools and media, and the aim has been to use these in appropriate roles. Thus efforts have been made to use literature, electronic documents, interactive documents and different kinds of interactive tools, such as simulations, in a way that would maximize their benefits but minimize their disadvantages (e.g. Gonzales et al. 2001). For example, Min (1992) concludes that the use of written sources, books and handouts as parallel media along with a computer is often motivated, and no attempt has 
been made to transfer all materials into electronic format. Min (1992) also submits that open simulation environments often work better when the instructions for their use include easily read and browsed (printed) documents, such as workbooks, alongside material on the computer display. Efforts have been made to produce and use content and documents, as well as tools, e.g., 'mindtools' (Jonassen, 2000), that facilitate thinking, which exploit the capabilities and interactive nature of the electronic medium, in this format. Preliminary research findings (simultaneous video and stimulated recall, group interview) support the effectiveness of this approach. A textbook and simulation in conjunction with an interactive WWW agent application to support them - an orientation agent - seem to work together as envisioned. Here the research has drawn on usability studies and the ideas of cognitive load theory; in other words, the study tools have been built to avoid students' having to divide their attention excessively among different focuses and activities. (e.g., Kapetilinin \& Nardi 1997; Wilson \& Cole 1996; Sweller, J. \& Chandler; Chandler\& Sweller 1991). Efforts have also been made to exploit edutainment (education \& entertainment) as part of the nature of tools and materials and game-like interactivity as factors that can enhance the learning process.

\section{THEORY OF TEACHING AND LEARNING, INSTRUCTIONAL DESIGN AND TECHNOLOGY SUPPORTING ONE ANOTHER}

The project has sought to link its focus - graphic simulations in electronic technology and electronics - in a theoretically justifiable way to the teaching-studying-learning process defined by Uljens (1997) in order to provide for a studying process that would produce high-level learning. (cf. Gokhale 1996).

The teaching has been designed to orient the student's studying and learning activity as an individual and a member of group, i.e., small groups towards Vygotsky's zone of proximal development (ZPD) using instructional design solutions and information technology (Lehtonen 2002; Ruokamo et al. 2002; Vygotksy 1978/1932; Wertsh 1985; Bransford et al. $2000,214-215)$. The aim has been to create a process in which the topic being studied and the related sub skills and knowledge are constructed in the group process. In the initial stage of the process, students engage in networkguided activities in which they externalize, communicate and visualize their ideas to others through speech, simulation tools and gestures as well as test the viability of their ideas using a simulation tool. In this way, the topics are 
gradually internalized (Galperin 1979; Podolskij 1997) and it becomes possible to gradually reduce the guidance, or orientation, of study, ultimately permitting the testing and application of what has been learned in a problembased project. Drawing on Vygotksy (1978/1932), the social interaction among the students occupies a central role in the instructional design model. The guidance tools and their effect remain at the student's and group's disposal throughout the process (book and orientation agent) should they wish to resort to them. This can be considered extremely important, not only for guidance of the student but also as an element which can give the student a sense of security and reduce situational anxiety, thereby contributing to learning (e.g., Farnill 2001; Min 1992; Bransford 2000). Preliminary analyses of the research data support this conclusion. When the subskills that have been mastered following the process described above, and different subskills practiced, and the students' knowledge of electronic technology and electronics has developed sufficiently, learning activity can continue with an open, problem-based period in which the students must not only test their knowledge and acquire new knowledge but also apply what they have learned during the first stage of the teaching.

The guiding/orienting function of this first stage is very important in light of the tools used in the present research, e.g., simulation programs for electronics incorporating open-ended problem solving. Jonsassen (2000, 156) observes, "[the tools] enable learners to represent their own thinking in the ways that they explore, manipulate and experiment with the environment" (cf. Gokhale 1996). However, Gonzales, Reitman \& Stango (2001) point put that one problem associated with tools that make use of open problem solving is that without teaching, learning and sufficient practice in the use of the tool itself (sufficient control of the tool) and without experimenting with and study of the tool in problem solving thereafter as well as acquisition and building up of sufficient knowledge and skills in the subject concerned as part of studying, the tools lead to superficial and game-like study activity which rarely results in high-level learning. Here, one may refer to Podolskij's (Podolskij) statement, based on neo-Galperinian theory, that only when a learner has been helped to internalize certain routine activities and these no longer place an undue cognitive load on his/her thought and activity should he/she have the opportunity to be given asks requiring creativity, such as open problemsolving tasks. For this reason the teaching described has been designed to include orientation as Galperin describes it, which seeks to ensure that subject matter is learned gradually and that, at the same time, the students have an opportunity to regulate the orientation and support offered to them in accordance with their needs to the minimum possible but to nevertheless 
keep these available should the student want to resort to them. (cf. Ausubel's Advance Organizers and Bruner's Scaffolding)

\section{GAMES AND EDUTAINMENT AS PART OF STUDYING}

In order to be interesting, the tools should also produce experiences and feelings, direct and strongly supported teaching, which is often necessary early in learning. Jonassen (2000) in fact observes that these strongly interactive tools motivate students precisely because the tools allow them to learn by doing instead of contenting themselves to watch and listen to a presentation of how the thing is done by someone else. (cf. Bransford et al. 2000). One's own activity and work as part of a group often involves emotions and experiences. Edutainment has a contribution to make here in that the computer does not lose its significance as a tool; rather, its distinctive features are augmented to produce emotions in and entertain the user (e.g., Kangas 1999; Ruokamo et al. 2002). Crawford (1984) notes, that the principal motivation for playing is a desire to learn - a desire to learn to control a situation. He maintains that the desire to play is a mechanism that is built into one and us which the designers of computer games make use of. For example, ramping levels of difficulty, immediate feedback, and the use of multimedia to produce different effects are some of the means by which these experiences are created in computer games.

The present research attempts to accommodate the requirement of edutainment through its choice of a commercial simulation. The simulation software chosen for the research from among a number of potential applications has proven to be a successful one in many respects.

\section{CONCLUSION}

In light of its current findings, the research project "Web-supported Mental Tools in Technology Education" has made it possible to test the theoretical bases described and thus yielded valuable information on how study using simulation tools and network applications that support these and more traditional media can be appropriately organized. A preliminary analysis indicates that P. J. Galperin's ideas of the gradually and guided internalization of relevant sub skills by guiding the process through different orientation phases seems to work in a network environment. The importance of taking edutainment into account in designing instruction also seems to be 
borne out. The final analysis will also produce a great deal of knowledge in this area, but at this stage in the research, where materials are being organized and analyzed, it is not possible to present more specific conclusions.

\section{REFERENCES}

Bransford, J., Brown, A.L. \& Cocking, R.R. (Eds.) (2000). How people learn. Washington, D.C.: National Academy Press.

Chandler, P., \& Sweller, J. (1991). Cognitive load theory and the format of instruction. Cognition and Instruction. 8, 293-332.

Crawford, C. (1984). The art of Computer game design. Berkley, USA: McGraw-Hill.

Farnill, D. (2001). Communication in a medical emergency. Dept of Behavioural Sciences. University of Sydney. Retrieved February 12, 2003 from http://www.gmp.usyd.edu.au/vguide/students/samplew/mscp/learningtopics/Kk9HHkf.htm 1

Galperin, P.J. (1979). Johdatus psykologiaan. Suom. Riitta Kauppila, Klaus Helkama Helsinki. Kansankulttuuri.

Gonzales, J. J., Reitman, L. \& Stagno, T. (2001). An Interactive System for Teaching Electronics. Seminar paper presented at the 2001 ED-media conference, Tampere. June 25-30. 2001.

Gokhale , A. 1996. Effectiveness of Computer Simulation for Enhancing Higher Order Thinking. Journal of Industrial Teacher Education. 33(4), 36-46. Retrieved February 12, 2003 from http://scholar.lib.vt.edu/ejournals/JTE/v33n4/jite-v33n4.gokhale.html

Jonassen, D.H. (2000). Computers as mindtools for schools. Engaging critical thinking. (2nd ed). NJ. Prentice Hall.

Kangas, S. (1999). Mukautuvat käyttöliittymät elektronisissa peleissä. In T. Honkela (Ed.), Pelit, tietokone ja ihminen. [Games, Computers and People]. (pp.128-134) Suomen tekoälyseuran julkaisuja. Symposiosarja No 15. University of Art and Design UIAH \& Finnish Association of Artificial Intelligence. Helsinki

Kapetelinin, V. \& Nardi, B.A. (1997). Activity Theory: Basic Concepts and Applications. Retrieved $\quad$ February $\quad 12, \quad 2003$ from http://www.acm.org/sigchi/chi97/proceedings/tutorial/bn.htm

Lehtonen, M. (2002a). Toward the Information Age Challenges in Technology Education. Modern learning methods \& learning media supported and mediated learning processes as part of the new university technology education curriculum. In J. Kantola,. \& T. Kananoj (Eds.), Looking at the Future: technical work in context of technology education. (pp.99119) University of Jyväskylä: Jyväskylä University Printing House.

Lehtonen, M. (2002b). Simulaatioiden avulla tapahtuvan oppimistoiminnan mallin ja sitä tukevien Web-pohjaisten välineiden kehittäminen teknisessä työssä ja teknologiakasvatuksessa. Paper presented at the 2002 ITK'02 Conference Workshop of Researchers. Ministry of Education and the University of Tampere Hypermedia Laboratory. 17.4.2002. Hämeenlinna, FI

Lehtonen, M. (2002). The Online Interactive Curriculum Portal as One Key to the WellStructured Learning Activity of Students. World Conference on Educational Multimedia, Hypermedia and Telecommunications. 2002(1), 1110-1115. [Online]. Available: http://dl.aace.org/10288 
Min, F.B. (1992). Parallel instruction, a theory for educational computer simulation. Interactive Learning International, 6(3), 117-183.

Podolskij, A. (1997). Instructional Design for Schooling. Developmental Issues. In S. Dijkstra et al. (Eds.) Instructional Design. International perspectives. (Vol. 2). Mahwah, NJ: Lawrence Erlbaum.

Vahtivuori , S., Ruokamo, H., Tella, S., \& Tuovinen, H. (2002). Pedagogical Models in the Design and Assessment of Network-Based Education. World Conference on Educational Multimedia, Hypermedia and Telecommunications. 2002(1), 1676-1681. [Online]. Available: http://dl.aace.org/10418

Sweller, J., \& Chandler, P. (1994). Why some material is difficult to learn. Cognition and Instruction, 12, 185-233.

Uljens, M. (1997). School didactics and learning. Hove, East Sussex: Psychology Press.

Wertsch, J. V. (1985). Vygotsky and the social formation of mind. Cambridge, MA: Harvard University Press.

Wilson, B. \& Cole, P. (1996). Improving Traditional Instruction. Cognitive Load Theory. Retrieved February 12, 2003 from http://carbon.cudenver.edu/ bwilson/cog/sweller.html

Vygotsky, L. S. (1978/1932). Mind in Society. Cambridge. Massachusetts. Harvard University Press.

\section{BIOGRAPHY}

Miika Lehtonen is researcher at MOMENTS (Models and Methods for Future Knowledge Construction: Interdisciplinary Implementations with Mobile Technologies) project. His research and development has recently focused on developing pedagogical models and tools for network-based learning utilizing the Vygotskian and neoGalperian ideas of 'mental tools' or 'mindtools' and Web based pedagogical agent orientation (cf. Jonassen 2000). His main interests lie at the area of using interactive \& constructive simulations effectively as mental tools for learning.

Miika Lehtonen University of Lapland, Faculty of Education, Centre for Media Pedagogy

P.O. Box 122, FIN-96101 Rovaniemi, FINLAND

Miika.Lehtonen@urova.fi

http://www.urova.fi/home/hkunta/milehton

http://amc.pori.tut.fi/moments 